\title{
The role of the Corynebacterium glutamicum rel gene in (p)ppGpp metabolism
}

\author{
Lutz Wehmeier, ${ }^{1}$ Andreas Schäfer, ${ }^{1}+$ Andreas Burkovski, ${ }^{2}$ \\ Reinhard Krämer, ${ }^{2}$ Undine Mechold, ${ }^{3}$ Horst Malke, ${ }^{3}$ \\ Alfred Pühler ${ }^{1}$ and Jörn Kalinowski ${ }^{1}$
}

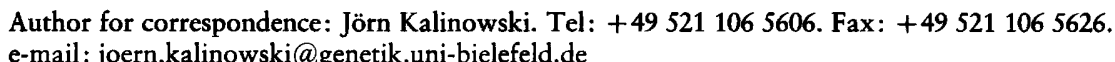

1 Lehrstuhl für Genetik, Fakultăt far Biologie, Universităt Bielefeld, D33501 Bielefeld, Germany

2 Institut für Biochemie 1 Universität zu Köln, D50674 Köln, Germany

3 Institut für Molekularbiologie, Universităt Jena, D-07745 Jena, Germany

\begin{abstract}
To investigate the metabolism of (p)ppGpp in amino-acid-producing coryneform bacteria, a PCR-based strategy using degenerate consensus oligonucleotides was applied to isolate the rel gene of Corynebacterium glutamicum ATCC 13032. The gene consists of 2283 nucleotides and encodes a protein of 760 amino acids with a molecular mass of $84.4 \mathrm{kDa}$. The amino acid sequence revealed extensive similarities to the related proteins RelA and Spot of Escherichia coli, which are known to be involved in (p)ppGpp biosynthesis and degradation. The $C$. glutamicum rel gene is located downstream of the apt gene encoding an adenine phosphoribosyltransferase, and an ORF with similarities to dciAE, which represents part of a dipeptide transport system in E. coll. A C. glutamicum mutant strain carrying a defined deletion in the rel gene was constructed. This mutant failed to accumulate (p)ppGpp in response to amino acid starvation. When overexpressed in $E$. coli, the C. glutamicum rel gene was able to reverse growth defects caused by an overexpressed relA gene. It is proposed that the $C$. glutamicum rel gene encodes a bifunctional enzyme with (p)ppGpp synthetase and (p)ppGpp-degrading activities.
\end{abstract}

Keywords: stringent response, (p)ppGpp, Corynebacterium, relA, spoT

\section{INTRODUCTION}

In Escherichia coli, amino acid starvation leads to pleiotropic metabolic alterations, termed the stringent response, mediated by the highly phosphorylated guanine nucleotides ppGpp and pppGpp [collectively abbreviated (p)ppGpp]. Accumulation of (p)ppGpp is also observed after other nutrient or environmental stresses, such as carbon source, nitrogen or phosphate limitation. This indicates that ( $\mathrm{p}$ )ppGpp also plays a central role in growth rate control. An elevated level of (p)ppGpp results in complex changes in the pattern of gene expression. While transcription of many genes and most stable RNA species is rapidly reduced, expression of stationary-phase-specific genes is induced and the expression of certain anabolic genes, for example amino

†Present address: Qiagen GmbH, Max-Volmer-Straße 4, D-40724 Hilden, Germany.

Abbreviation: PEl, polyethyleneimine.

The GenBank accession number for the $4.08 \mathrm{~kb}$ rel region reported in this paper is AF038651. acid biosynthetic genes, is increased (reviewed by Cashel et al., 1996; Codon et al., 1995). In addition, it has been shown that the stringent response is correlated with increased glutamate excretion in E. coli (Burkovski et al., 1995).

The related proteins RelA and SpoT are involved in the synthesis of (p)ppGpp in E. coli. The RelA protein, responsible for (p)ppGpp biosynthesis during amino acid deprivation, is a ribosome-associated enzyme catalysing the transfer of a pyrophosphoryl group of ATP to the $3^{\prime}$-hydroxyl position of GTP or GDP. The enzyme is active when uncharged codon-specific tRNAs bind to the ribosomal A-site (Cochran \& Byrne, 1974; Goldman $\&$ Jakubowski, 1990). The SpoT protein was originally identified as a (p)ppGpp 3'-pyrophosphohydrolase responsible for degrading (p)ppGpp to GTP or GDP and pyrophosphate (An et al., 1979). However, the presence of (p)ppGpp in relA mutant strains (Hernandez \& Bremer, 1991), the absence of all detectable (p)ppGpp in relA/spoT double mutants (Xiao et al., 1991) and the fact that RelA and SpoT have extensive amino acid sequence similarity throughout their length (Metzger $e t$ al., 1989) led to the proposal that SpoT is a bifunctional 
Table 1. Bacterial strains and plasmids used

\begin{tabular}{|c|c|c|}
\hline Strain or plasmid & Relevant characteristic & Source or reference \\
\hline \multicolumn{3}{|l|}{ C. glutamicum } \\
\hline ATCC 13032 & Wild-type strain, $\mathbf{N x}^{\mathbf{R}}$ & ATCC \\
\hline RES167 & $\begin{array}{l}\text { Restriction-deficient mutant of ATCC } 13032, \\
\Delta c g l R I \text { cglRII }\end{array}$ & Universität Bielefeld \\
\hline RM4 & $\begin{array}{l}\text { Restriction-deficient mutant of ATCC } 13032 \\
\text { obtained by chemical mutagenesis }\end{array}$ & Universität Bielefeld \\
\hline ASC30 & $\begin{array}{l}\text { RES167 carrying pASC20 integrated in the } \\
\text { chromosome }\end{array}$ & This work \\
\hline RES167 $\Delta r e l$ & rel deletion mutant of RES167 & This work \\
\hline RM4 Arel & rel deletion mutant of RM4 & This work \\
\hline \multicolumn{3}{|l|}{ E. coli } \\
\hline DH5 $\alpha$ MCR & $\begin{array}{l}\mathrm{F}^{-} \text {supE44 endA thi-1 recA1 gyrA96 relA1 deoR } \\
\Delta(\text { lac-argF }) \mathrm{U} 196 \text { } \phi 80 \mathrm{~d} \text { lacZ M15 mcrA } \Delta(\mathrm{mmr} \\
\text { hsdRMS mcrBC) }\end{array}$ & Grant et al. (1990) \\
\hline S17-1 & $\begin{array}{l}\text { bsdR pro recA carrying RP4-2-Tc:: } \mathrm{Mu} \text { in the } \\
\text { chromosome }\end{array}$ & Simon et al. (1983) \\
\hline CF1648 & Wild-type MG1655 & Xiao et al. (1991) \\
\hline CF1652 & CF1648 $\Delta$ relA251 & Xiao et al. (1991) \\
\hline \multicolumn{3}{|l|}{ Plasmids } \\
\hline pK18mob & $\begin{array}{l}\text { Mobilizable cloning and sequencing vector, } \\
\mathrm{Km}^{\mathrm{R}}\end{array}$ & Schäfer et al. (1994) \\
\hline pTrc99A & $\begin{array}{l}\text { pKK233-2-derivative, } \operatorname{trcP}, \operatorname{lacI}^{\mathrm{q}} \text {, } \mathrm{pUC18} \\
\text { polylinker, } \mathrm{Ap}^{\mathrm{R}}\end{array}$ & Amann et al. (1988) \\
\hline pASC20 & $\begin{array}{l}\text { pK18mob carrying an } 140 \text { bp PCR amplificate } \\
\text { of the C. glutamicum rel gene }\end{array}$ & This work \\
\hline pASC21 & $\begin{array}{l}\text { pK18mob with a } 2 \cdot 2 \mathrm{~kb} \text { EcoRI insertion } \\
\text { containing the } 5^{\prime} \text { region of rel }\end{array}$ & This work \\
\hline pASC22 & $\begin{array}{l}\text { pK18mob with a } 2 \cdot 7 \mathrm{~kb} \text { HindIII insertion } \\
\text { containing the } 3^{\prime} \text { region of rel }\end{array}$ & This work \\
\hline pASC25 & $\begin{array}{l}\text { pK18mob carrying a } 1.8 \mathrm{~kb} \text { Xhol PCR } \\
\text { amplificate of } r e l\end{array}$ & This work \\
\hline pASC26 & pASC25 lacking a 400 bp SalI fragment & This work \\
\hline pLW60 & $\begin{array}{l}\text { pK } 18 m o b \text { containing an } 800 \mathrm{bp} E c o \mathrm{RI}-\mathrm{Bam} \mathrm{HI} \\
\text { insert originating from pASC } 21\end{array}$ & This work \\
\hline pLW65 & $\begin{array}{l}\text { pK } 18 m o b \text { carrying a } 4.75 \mathrm{~kb} \text { HindIII apt-rel } \\
\text { region of C. glutamicum }\end{array}$ & This work \\
\hline pLW68 & $\begin{array}{l}\text { pK18mob harbouring a } 3.5 \mathrm{~kb} \text { XhoI-HindIII rel } \\
\text { region orginating from } \mathrm{pLW} 65\end{array}$ & This work \\
\hline pSFS10 & $\begin{array}{l}\text { pTrc99A harbouring relA downstream of the } \\
\text { trc promoter }\end{array}$ & This work \\
\hline
\end{tabular}

enzyme, responsible for the second source of activity for the formation of (p)ppGpp (Murray \& Bremer, 1996). A mutational analysis of the spoT gene revealed that the two catalytic sites of SpoT are located in distinct but overlapping regions of the $\mathrm{N}$-terminal region (Gentry \& Cashel, 1996). The synthetase activity of SpoT is active during energy exhaustion and provides a basal level of (p)ppGpp during exponential growth (Ryals et al., 1982).

In contrast to the situation described for E. coli, a chromosomal deletion in the Bacillus subtilis relA gene eliminates (p)ppGpp synthesis in response to both amino acid deprivation and glucose exhaustion (Wendrich $\&$
Marahiel, 1997). Moreover, a mutant strain of Streptococcus equisimilis H46A, carrying an insertion in a relA/spoT homologous gene, termed rel, fails to accumulate (p)ppGpp in response to amino acid starvation and was shown to encode an additional (p)ppGpp hydrolase activity. These findings support the idea that in some bacteria one gene mediates the functions that reside in separate E. coli genes (Mechold et al., 1996).

The Gram-positive, nonsporulating soil micro-organism Corynebacterium glutamicum is of special interest for the industrial production of amino acids, nucleotides and numerous metabolites (Wohlleben et al., 1993). In the last decade, genetic tools have been developed for 


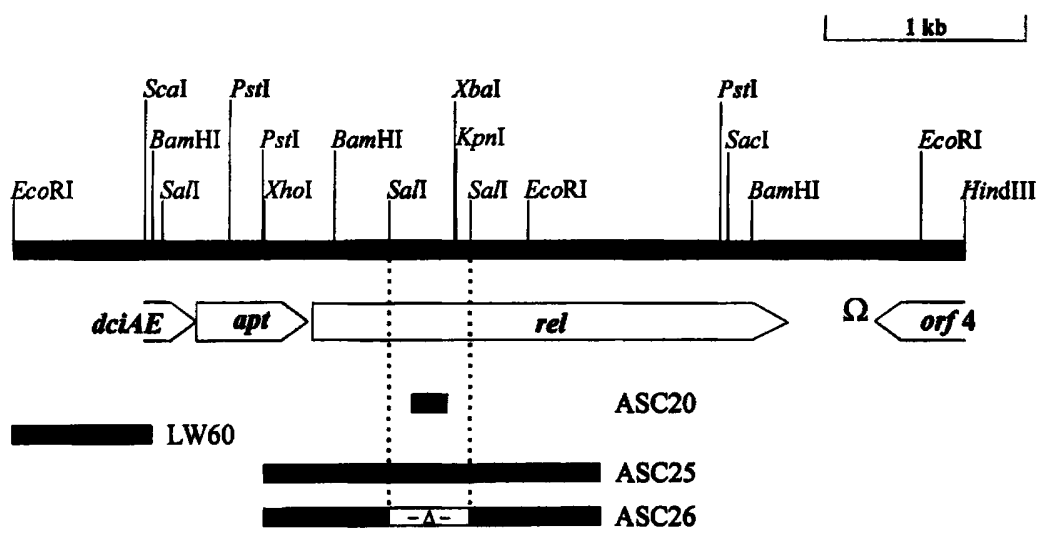

Fig. 1. Restriction map of the contiguous $4.75 \mathrm{~kb}$ apt-rel region from C. glutamicum ATCC 13032. The positions of the ORFs (dciAE, apt, rel, orf 4) are indicated by arrows and the position of the transcriptional terminator of orf 4 is marked $(\Omega)$. The location of the $140 \mathrm{bp}$ PCR product (ASC20) and the $800 \mathrm{bp}$ ECORI-BamHI fragment upstream of apt used for the isolation of the entire rel gene (LW60) are shown under the restriction map. Also indicated are the fragments used for the construction of a chromosomal rel deletion (ASC25, ASC26). For this purpose, a $1.8 \mathrm{~kb}$ internal fragment of the apt-rel region was amplified from the $C$. glutamicum chromosome (ASC25) and cloned into pK18mobsacB. The resultant plasmid, pASC25, was cut with Sall and religated, to form plasmid pASC26; this carries a modified apt-rel fragment which lacks a central 400 bp Sall fragment (ASC26).

this group of bacteria and a variety of genes involved in amino acid biosynthesis have been cloned. Since then, the synthesis of selected amino acids has been improved by genetic engineering and amplification of relevant biosynthetic genes, resulting in highly productive strains - so-called amino acid hyperproducers (Sahm et al., 1995). A recent study in C. glutamicum has pointed out that, as in E. coli, RNA synthesis as well as growth rate are inversely correlated with the cellular ppGpp concentration (Ruklisha et al., 1995). Therefore, knowledge about the genetic background of (p)ppGpp metabolism in C. glutamicum could possibly lead to a better understanding of the stringent response in these bacteria.

In the present study we report the identification and molecular characterization of a C. glutamicum gene, termed rel, which shows significant homology to relA and $s p o T$ genes. (p)ppGpp accumulation assays in wildtype and in rel mutant strains, as well as expression studies of the rel gene in E. coli, provide considerable evidence that $r e l$ is bifunctional, encoding a (p)ppGpp synthetase as well as a (p)ppGppase.

\section{METHODS}

Bacterial strains, plasmids and growth conditions. All bacterial strains and plasmids used in this study are listed in Table 1. E. coli and C. glutamicum strains were routinely grown in Luria-Bertani (LB) medium (Sambrook et al., 1989) at $37^{\circ} \mathrm{C}$ and $30^{\circ} \mathrm{C}$, respectively. Antibiotics used for plasmid selection were kanamycin $\left(50 \mu \mathrm{g} \mathrm{ml}^{-1}\right.$ for $E$. coli, $25 \mu \mathrm{g} \mathrm{m}^{-1}$ for $C$. glutamicum) and ampicillin $\left(100 \mu \mathrm{g} \mathrm{ml}^{-1}\right.$ for E. coli).

DNA manipulation and DNA transfer. Plasmid DNA from $E$. coli was isolated by the alkaline lysis technique (Sambrook et al., 1989). Total chromosomal DNA of C. glutamicum was prepared as described by Tauch et al. (1995). DNA restriction, agarose gel electrophoresis, Klenow treatment and ligation were carried out as described by Sambrook et al. (1989). Enzymes for DNA manipulation were purchased from Pharmacia or Boehringer. DNA restriction fragments required for cloning were isolated from agarose gels using the US BiocleanMP Kit (United States Biochemicals). All cloning procedures were carried out using E. coli DH5 $\alpha$ MCR (Grant et al., 1990). Plasmid DNA was introduced into $E$. coli strains by electroporation (Tauch et al., 1994). Intergeneric conjugal transfer of plasmids from E. coli to C. glutamicum followed the mating procedure described by Schäfer et al. (1990). Transconjugants were selected on LB agar containing $50 \mu \mathrm{g}$ nalidixic acid $\mathrm{ml}^{-1}$ and $25 \mu \mathrm{g}$ kanamycin $\mathrm{ml}^{-1}$.

Polymerase chain reactions. The synthetic oligonucleotides $5^{\prime}$-GACCG(GT)TT(GA)CATAA(CT)ATGCG and 5'-GAAAG(CA)CAG(AG)TCTTC(TC)AA (nucleotides in parentheses indicate positions of degeneracy) were used for the amplification of a $140 \mathrm{bp}$ internal fragment of the C. glutamicum rel gene with Taq DNA polymerase from Gibco-BRL. The promoterless $E$. coli relA gene was amplified with the PCR primers 5'-ACTGGCGATGCTGGATATGT and 5'GATTGAGCGCCTGCATTAAC using $P f u$ DNA polymerase (Stratagene). PCR experiments were carried out with a PCT-100 thermocycler (MJ Research). Initial denaturation was conducted at $94^{\circ} \mathrm{C}$ for 2 min followed by $90 \mathrm{~s}$ denaturation, $90 \mathrm{~s}$ annealing at $T_{\mathrm{d}(\text { primer } 1 \text { or 2) }}-5^{\circ} \mathrm{C}$ (Suggs et al., 1981) and extension at $72{ }^{\circ} \mathrm{C}$ for $90 \mathrm{~s}$ ( $\mathrm{Taq}$ polymerase) or $6 \mathrm{~min}$ ( $P f u$ polymerase), respectively. This cycle was repeated 30 times followed by a final extension step for $10 \mathrm{~min}$ at $72^{\circ} \mathrm{C}$. PCR products were purified using the Qiagen PCR Purification Spin Kit from Qiagen.

Southern hybridization. Chromosomal DNA of C. glutamicum was digested with restriction enzymes and separated on $0.8 \%$ agarose gels. Southern blots were prepared on Hybond-N nylon membranes (Amersham) using the vaccum blotter Vacu-Gene (Pharmacia). Fixation of DNA, labelling of DNA probes and hybridization were performed with the nonradioactive DIG DNA Labelling and Detection Kit from Boehringer.

DNA sequencing and sequence analysis. Unidirectional deletions were introduced into the plasmid inserts of pASC20 and pASC21 using the Double Stranded Nested Deletion Kit (Pharmacia). DNA sequencing analysis was performed with DNA isolated and purified using the Qiagen Plasmid Mini Kit (Qiagen) by the dideoxy chain-termination method of Sanger et al. (1977). The sequencing reactions were carried out with the AutoRead Sequencing Kit from Pharmacia. Electrophoretic analysis and detection of the sequenced products 
Rel_C.glu SpoT_M.Iep RelA_S.coe Rel_S.egi

Rel_C.glu SpoT_M.Iep RelA_S.coe Rel_S.eqi

Rel_C.glu SpoT_M. Iep RelA_S.coe Rel_S.eqi

Rel_C.glu SpoT_M. lep RelA_S.coe Rel_S.eqi

Rel_C.glu SpoT_M.Iep RelA_S.coe Rel_S.eqi

Rel_C.glu SpoT_M.1ep RelA_S.coe Rel_S.eqi

Rel_C.glu SpoT_M. lep RelA_S.coe Rel_S.eqi

Rel_C.glu SpoT_M.Iep RelA_S.coe Rel_S.eqi

ReI_C.glu SpoT_M.Iep RelA_S.coe Rel_S.eqi

Rel_C.glu SpoT_M.1ep RelA_S.coe Rel_S,eqi

Rel_C.glu SpoT_M. Iep RelA_S.coe Rel_S.eqi

Rel_C.glu SpoT_M. Iep RelA_S.coe Rel_S.eqi

MPDEAQPLTAAKPESASASAAKPAPSAPQAKNDTHGPIQHAPAAPVDKPAEQQPRPKPLPAERPQNAPVVRAPAG

QKS-SMGVRSMSARLARSLTGNRVRTNPVLDPLLSIHRQFHP---RADVQVLERAYDTAERLIDGVIRKBCDPYI KTS-SSASRRVRARIARRMTAQRSTISPVLEPLVAVIKEFYP---KANLSIVQRAFEVADQREASQLRRSGDPYI QPARSGSSNRVRARLARLGVQRANPYNPVLEPLLRIVRGNDPKIETSTLRQIERAYQVAERWERGQKRKSGDPYI

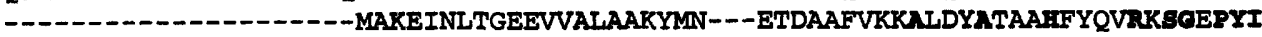

TEPLAVATIANEIGMDTTYLVAALLEDTVADTDYSLDDLTRDFOEEVARLVDGVHCLDKVALG-AAAEAETIRK TZPLAVANILAELGMDITYLVAALLIDTVADIGYTLEALSEEFODEVGHLVCVTKLDRVVLG-SAAEGETIRK

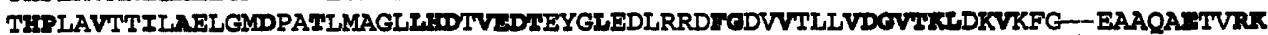
VEPIQVAGILADLHLDAVTVACGFLFDVVETDITLDNIEFDFCKDVRDIVDCVIUTGKVEYKSHEEQLAENHRX

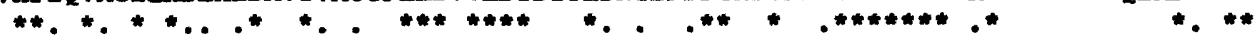

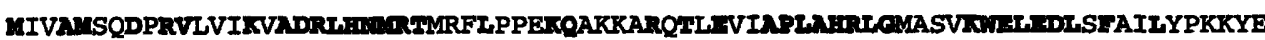

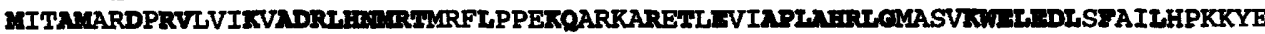

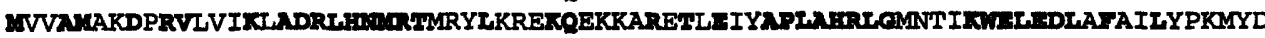

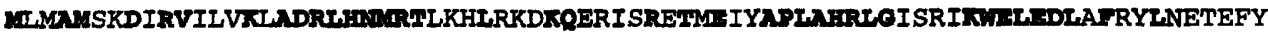

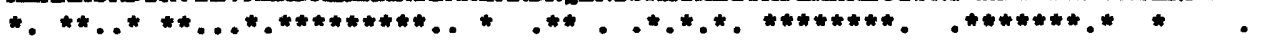

EIVRLVADRAPSRDRYLKEIIDQVTGGLRENNIAAGVLARPATYWSIYQUUIVRGRDEDDIFDLVGIRILVDNVN EIVRLVAGRAPSRDTYLAKVRAEI ISTLGASKIKATVEORPKGYWSIYQIUIVKGRDFDDIHDLVGIRILCDEIR EIVRLVAERAPKRDEYLAVVTDEVQQDLRAARIKATVTERPARYYSVYQIOIVRGRDEAEIYDVVGIRVLVDTVR KISHMMNEKRREREALVDDIVTKIKSYTTEQGLFGDVYORPXHIYSIYRORDKKKRIDQIFDL IAIRCVMETQS

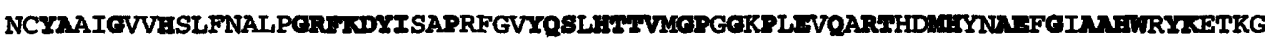

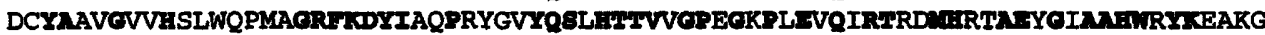

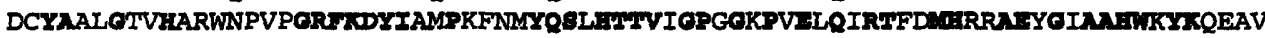

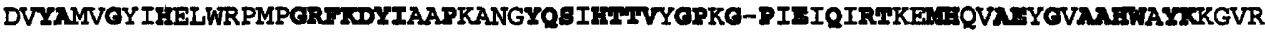

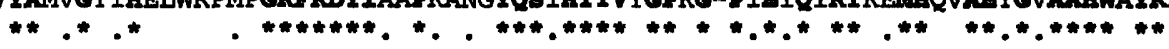

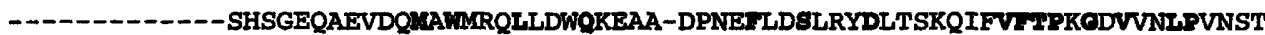
R-- - ---NGVLHPHAAAEIDDUAMMRQLLDWQREAA-EPGEILESLRYDLAVQEIFVITPKODVITLPTGST AGASKVRTDAPKSSGKSKDDHLNDWAWLRQLLDWQKETE-DPGEILESLRFDLSRNEVFVITPKCDVIALPAGAT -

$$
\text { *...*..* . . .**..*. ..********. }
$$

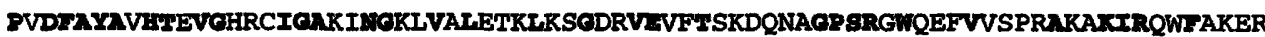

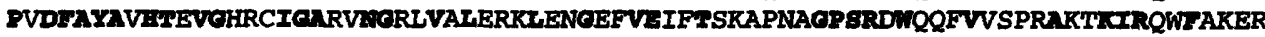
PVDFAYAVETEVGHRTIGARVAORLVPLESTLDNODLVEVFTSKAAGAGPSRDWLGFVKSPRARNKCRAWFSKER PIDFAYA IETQVGERAIGUKVWORMVPLTAKLKTEDVVIIVINPN-SFOPERDWIKLVKTNKARNIIRQFKKNQD

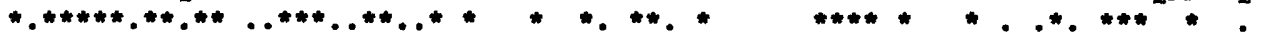

REEYLEAGRDALAAVIQRGGL PMIARLFTASSMKTVATELHYPDVDALYTAIOSASVSAQHVVIRLMAIFGDEEDREEALEACKDAMAREVRRGGLPLQRLVNGESMAAVARELHYIDVSALYTAICECHV8ARHVVQRLLAELGGIDQRDEAIEQCKDAIVRAMRKQNLPIQRILTGDSLVTLAHEMRY SDISAI YAAI OEGHVBAPNIVQKLVQALGGEEAKELSVNKGRDMLVSYFQEQGYVANKYLDKKRIEAIIPKVSVKSEESLYAAVGFEDI IPVSVFWKLTEKERREEER

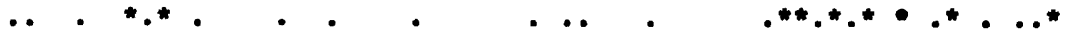

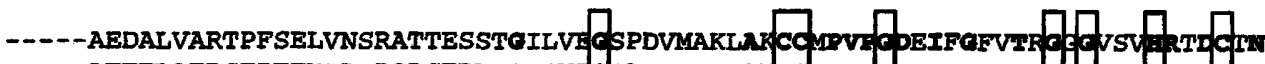

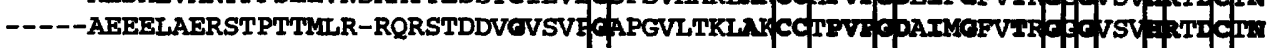

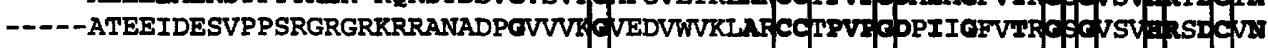

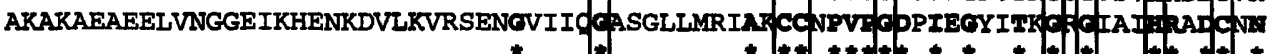

VEKLKEEPERIVSVSWASEGQGSVFSATLQLEALDAAGLFELTRVINEQKVSVTAMNSHCSED-RVATVRFTFA TASLOQOA-ARIIEVLWAPSSS-SVFLVAIOVEAIDRHRIYIDITRAIADERVDILSASVTTSGD-RVAISRFTIF VDSLSREPERILEVEWAPTQS-SVFLVAIQVEAIDASRLLSDVTRVLSDQHVNILSAAVQTSRD-RVATSRFTFE IKSQDGYQERLIEVEWDLDNSSKDYQAEIDIYGLNRRGLLNDVLQILSNSTKSISTVNAQPTKDMKFANIHVSFG

$$
\text { ***** }
$$$$
\text { .. . . . .* }
$$

VSDTROTGSLMTOLRNAEGVFDVRVTSGG---

Fig. 2. Multiple alignment of the deduced amino acid sequence of the $C$. glutamicum Rel protein with homologues from other bacteria. Identical amino acids are typed in bold and marked by asterisks; a dot represents positions with conservative substitutions. The aligned cysteine, glycine and histidine residues in a conserved C-terminal region, possibly acting as a metal-binding domain, are boxed. C.glu, C. glutamicum; M.lep, M. leprae (EMBL U00011); S.coe, Streptomyces coelicolor A3(2) (Chakraburtty et al., 1996); S.eqi, S. equisimilis H46A (Mechold et al., 1993). 
were accomplished with the help of an ALF DNA sequencer from Pharmacia. Computer-assisted compilation of the DNA sequences was done with the computer programs of Staden (1986) and Pearson \& Lipman (1988). Searches for amino acid similarities were carried out with the BLAST e-mail service (Altschul et al., 1990). Multiple alignments were computed by the CLUSTAL w program (Thompson et al., 1994).

Construction of rel deletion mutants of C. glutamicum RES167 and RM4. Defined chromosomal deletions in the rel gene of $C$. glutamicum RES167 and RM4 were constructed using the sacB system, which helps to identify an allelic exchange by homologous recombination (Schäfer et al., 1994). For this purpose, a $1.8 \mathrm{~kb}$ internal fragment of the apt-rel region was amplified from the C. glutamicum chromosome using PCR with the oligonucleotides ASC25-1 (5'-CTTGAATACGGCACTGCA) and ASC25-2 (5'-TCTTGGCCTTTGCTCGAG). The PCR primers ASC25-1 and ASC25-2 were deduced from the known nucleotide sequence (ASC25-1, nt 582-599, ASC252 , nt 2358-2341). The downstream primer ASC25-2 contained an A2345 to T exchange leading to an $\mathrm{XhoI}$ site. The purified $1.8 \mathrm{~kb}$ amplificate was cleaved with $\mathrm{XhoI}$ and cloned into the Sall-digested E. coli vector pK18mobsacB (Schäfer et al., 1994), yielding pASC25 (Fig. 1). Subsequently, pASC25 was cut with SalI to delete an internal 400 bp fragment (corresponding to amino acid residues 129-266) of the $C$. glutamicum rel gene and religated. The resulting plasmid pASC26 (Fig. 1) was transferred to E. coli S17-1 and mobilized to C. glutamicum RES167 and RM4 by conjugation. The plasmid can only establish itself by homologous recombination into the chromosome in such a way that the resulting $C$. glutamicum strains carried the modified apt-rel region and the wild-type genes separated by vector sequences. Excision of the plasmid can be selected for by growing the cells on LB agar containing $10 \%$ sucrose. Cells able to grow on this medium have lost the plasmid due to a second cross-over event that either restores the wild-type gene arrangement or leads to a mutant strain carrying a defined deletion and a frame shift mutation in the chromosome. Southern hybridizations using HindIII-digested chromosomal DNAs of sucrose-resistant clones and labelled pASC25 DNA were performed to distinguish between both genomic situations and to verify the construction of the chromosomal rel deletion.

Measurement of (p)ppGpp accumulation. Strains were screened for patterns of (p)ppGpp accumulation using the rapid screening method described by Cashel (1994). Nonuniformly ${ }^{32} \mathrm{P}_{i}$-labelled $E$. coli and C. glutamicum cells were obtained by growing the strains overnight on LB plates, followed by dispersion of single colonies in phosphate-free MOPS minimal medium and incubation with MOPS medium containing $10 \mu \mathrm{Ci}^{32} \mathrm{P}_{1} \mathrm{ml}^{-1}\left(3.7 \times 10^{5} \mathrm{~Bq} \mathrm{ml}^{-1}\right)$ for $30 \mathrm{~min}$ at $37^{\circ} \mathrm{C}$. For amino acid starvation responses, the colonies were resuspended in amino-acid-free, phosphate-free MOPS medium supplemented with DL-serine hydroxamate $\left(1 \mathrm{mg} \mathrm{ml}^{-1}\right)$ and $\mathrm{L}$-valine $\left(0.5 \mathrm{mg} \mathrm{ml}^{-1}\right)$. The samples were then mixed with $13 \mathrm{M}$ formic acid and three freeze-thaw cycles were performed. Afterwards, the samples were centrifuged and $5 \mu \mathrm{l}$ samples of supernatant were subjected to one-dimensional polyethyleneimine (PEI) TLC developed with $1.5 \mathrm{M}$ potassium phosphate ( $\mathrm{pH} 3.4$ ). Nucleotide abundance was quantified by PhosphorImager analysis (Fuji BAS1000). Amounts of pppGpp and ppGpp were expressed as fractions of the total activity of blank-corrected GTP, ppGpp and pppGpp. The nucleotide identities were verified by cochromatography with standards after two-dimensional PEI-TLC in $3.3 \mathrm{M}$ ammonium formate $/ 4.2 \%$ ammonium borate $(\mathrm{pH}$ 7) (first dimension) and $1.5 \mathrm{M} \mathrm{KP}_{\mathrm{i}}$ (pH 3.4) (second dimension).

\section{RESULTS}

\section{Cloning of a C. glutamicum DNA fragment carrying sequences homologous to internal fragments of relA and spot genes of other bacterial species}

We used a PCR-based strategy to clone relA/spoT homologous genes from C. glutamicum. A sequence alignment of spoT from Mycobacterium leprae (EMBL 00011) and the rel gene from Streptococcus equisimilis (Mechold et al., 1993) revealed several conserved nucleotide regions. These regions were chosen for the design of degenerate oligonucleotides acting as primers in PCR experiments with chromosomal DNA from $C$. glutamicum as a template. One primer pair led to an amplified product of approximately $140 \mathrm{bp}$ corresponding to the size expected for a relA- or spoT-like gene fragment (ASC20 in Fig. 1). The PCR product was treated with Klenow polymerase and cloned in SmaIcleaved $\mathrm{pK} 18 m o b$, yielding pASC20. The determination of the DNA sequence of the pASC20 $140 \mathrm{bp}$ insert using standard sequencing primers revealed homology to internal fragments of relA- and spoT-related genes. Its origin from C. glutamicum was verified by using pASC20 as probe in a Southern blot experiment with $C$. glutamicum chromosomal DNA (data not shown).

The missing $5^{\prime}$ and $3^{\prime}$ regions of the gene were isolated by applying the plasmid rescue technique. Plasmid pASC20 was introduced into $E$. coli S17-1 by electroporation and mobilized into C. glutamicum RES167. The plasmid can only establish itself by integration into the chromosome via homologous recombination, yielding the strain C. glutamicum ASC30. Specific integration was confirmed by Southern hybridization with pASC20 as a probe (data not shown). To isolate adjacent chromosomal fragments, total DNA of C. glutamicum ASC30 was isolated, cut with EcoRI $\left(5^{\prime}\right.$ region) and HindIII ( $3^{\prime}$ region) and finally religated. The ligation mixtures were subsequently transformed into $E$. coli DH5 $\alpha$ MCR. The resulting plasmids pASC21 and pASC22 carried insertions of approximately $2 \cdot 2 \mathrm{~kb}$ and $2.7 \mathrm{~kb}$, respectively. Both plasmids are overlapping by the $140 \mathrm{bp}$ fragment used for integration and therefore represent a contiguous $4.75 \mathrm{~kb}$ DNA region of the $C$. glutamicum chromosome, of which a restriction map is shown in Fig. 1.

\section{DNA sequence analysis of the isolated DNA region identified the putative $C$. glutamicum rel gene}

The sequence of a 4077 bp ScaI-HindIII region was determined, represented by a $1.5 \mathrm{~kb}$ ScaI-HindIII fragment of the pASC21 insert and the complete $2.7 \mathrm{~kb}$ EcoRI-HindIII insertion of pASC22. The overall G +C content of the sequenced fragment is about $53 \mathrm{~mol} \%$, which agrees well with the range of $51 \cdot 2-54.4 \mathrm{~mol} \%$ reported for the C. glutamicum chromosome (Malumbres et al., 1993). A computer-assisted analysis of the coding probability (Staden, 1986) revealed four ORFs with protein coding character (Fig. 1). 


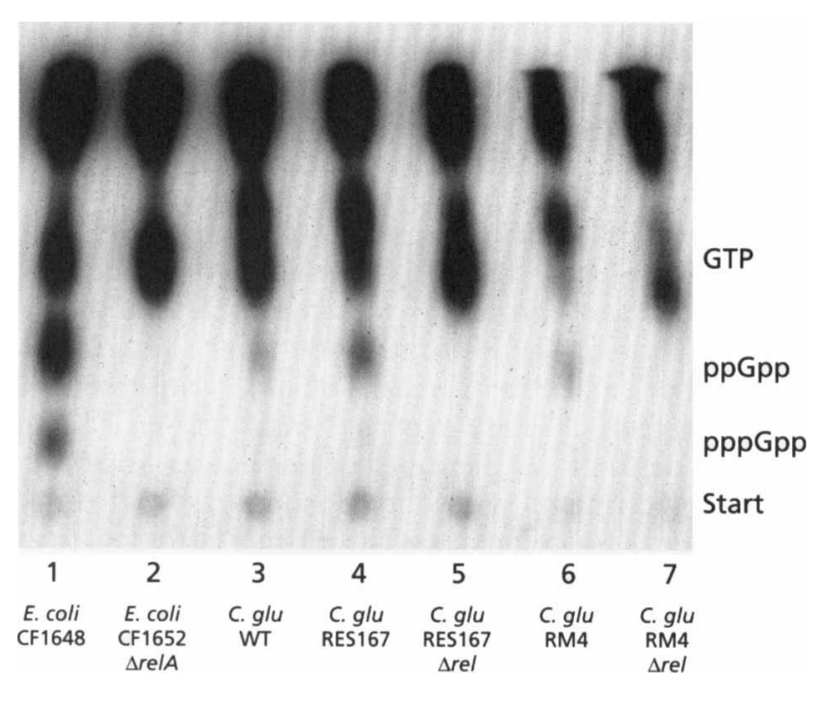

Fig. 3. Accumulation of (p)ppGpp in C. glutamicum wild-type and rel deletion mutants in response to amino acid starvation. Lanes: 1, E. coli CF1648, wild-type; 3, C. glutamicum ATCC 13032, wild-type; 4 and 6, RES167 and RM4, restriction-deficient derivatives of ATCC 13032; 2, CF1652, $\Delta$ relA; 5 and 7, $\Delta$ rel hosts of RES167 and RM4. Cultures were non-uniformly labelled with ${ }^{32} \mathrm{P}_{1}$ and amino acid starved after growth on LB plates, as described in Methods. The positions of standards after PEI-TLC development in $1.5 \mathrm{M} \mathrm{KH}_{2} \mathrm{PO}_{4}$ are indicated on the right. C.glu, C. glutamicum.

The largest ORF within this region, ORF 1 (nt 849-3131), encodes a protein of 760 amino acid residues with a calculated molecular mass of $84 \cdot 374 \mathrm{kDa}$ and a deduced isoelectric point of 6.53. Eight nucleotides upstream of the putative ATG start codon a sequence (AAAGGCGG) that is complementary to the $3^{\prime}$ end of the 16S rRNA of C. glutamicum was detected ( $\mathrm{J}$. Kalinowski, unpublished data), probably acting as a ribosome-binding site. A putative promoter region resembling the consensus -35 and -10 sequences of $E$. coli and C. glutamicum promoters (Hawley \& McClure, 1983; Patek et al., 1995) is located 69 nucleotides upstream of the ATG start codon. Sequence comparison of the deduced ORF 1 protein revealed significant homology to RelA and SpoT equivalents from other bacteria (Fig. 2), including Streptomyces coelicolor (Chakraburtty et al., 1996) and Streptococcus equisimilis (Mechold et al., 1993), displaying $73 \%$ and $65 \%$ homology, respectively. The highest degree of homology was found to SpoT of M. leprae (EMBL U00011) with $82 \%$ similar amino acid residues. Of particular significance was the alignability of three cysteines, a histidine and several glycine residues in a conserved Cterminal segment (boxed in Fig. 2), also appearing in $E$. coli SpoT (Sarubbi et al., 1988) and in the RelA proteins of E. coli (Metzger et al., 1988) and Vibrio sp. (Flärdh et al., 1994). These residues are possibly involved in metal binding (Berg, 1986). The similarities of the nucleotide sequences as well as the amino acid sequences prompted us to term ORF 1 as the putative C. glutamicum rel gene.
ORF 2, which is located upstream of rel, consists of $558 \mathrm{nt}$ (nt 264-821) and shows a G + C content of 53.8 $\mathrm{mol} \%$. A potential ribosome-binding site is located $9 \mathrm{nt}$ upstream of the predicted translational startpoint. Computer-assisted searches did not provide typical promoter sequences upstream of its GTG start codon. ORF 2 encodes a protein of 185 amino acid residues with a calculated molecular mass of $19.531 \mathrm{kDa}$, a deduced isoelectric point of 4.49 and a high degree of similarity to adenine phosphoribosyltransferases (APT) from a variety of organisms. The most similar one found by database searches was the APT protein of $S$. coelicolor, showing $60 \%$ amino acid homology. In a salvage reaction less costly than de novo synthesis, APT catalyses the conversion of adenine and 5-phosphoribosyl pyrophosphate to AMP (Hershey \& Taylor, 1986). Because of the high degree of sequence similarity, ORF 2 was termed apt.

ORF 3 is located upstream of $a p t$ and is not completely represented on the isolated fragment. It terminates at a TAG stop codon (nt 262-264) immediately in front of the apt start codon. Database searches displayed similarity to dciAE from $M$. leprae ( $41 \%$ identity and $64 \%$ similarity in 39 amino acids overlap); ORF 3 was accordingly named $d c i A E$. The DciAE protein of $B$. subtilis and $E$. coli probably acts as a peptide-binding protein as part of the DciA protein complex, which forms a dipeptide transport system (Mathiopoulos et al., 1991).

ORF 4, also not completely present on the sequenced fragment, is located downstream of rel and in the opposite orientation (nt 3691-4077). Comparison of the amino acid sequence deduced from ORF 4 with databases showed no significant similarity to known proteins. In the non-coding region between $\mathrm{rel}$ and ORF 4, a $32 \mathrm{nt}$ inverted repeat is present, which may act as a $\rho$ independent transcriptional terminator.

\section{A C. glutamicum rel mutant is unable to accumulate (p)ppGpp when starved for amino acids}

To assess the role of the C. glutamicum rel gene in (p)ppGpp synthesis, we constructed rel mutants of the restriction-deficient wild-type derivatives C. glutamicum RES167 and RM4 using the pK18mobsacB vector system (Schäfer et al., 1994) to select for rare homologous recombination events. (See Methods for a detailed experimental procedure of the strain construction.) The resulting strains C. glutamicum RES167 $\Delta$ rel and RM4 $\Delta r e l$, carry a modified gene that lacks a central $400 \mathrm{bp}$ Sall fragment (corresponding to amino acid residues $129-266$ ), resulting in a frame shift mutation ensuring its complete knock out.

We determined the effect of a non-functional rel gene on (p)ppGpp synthesis of the constructed rel mutant strains subjected to amino acid starvation. Cellular levels of (p)ppGpp were measured as described in Methods. Conditions of amino acid deprivation were imposed by the supplement of DL-serine hydroxamate, which in- 


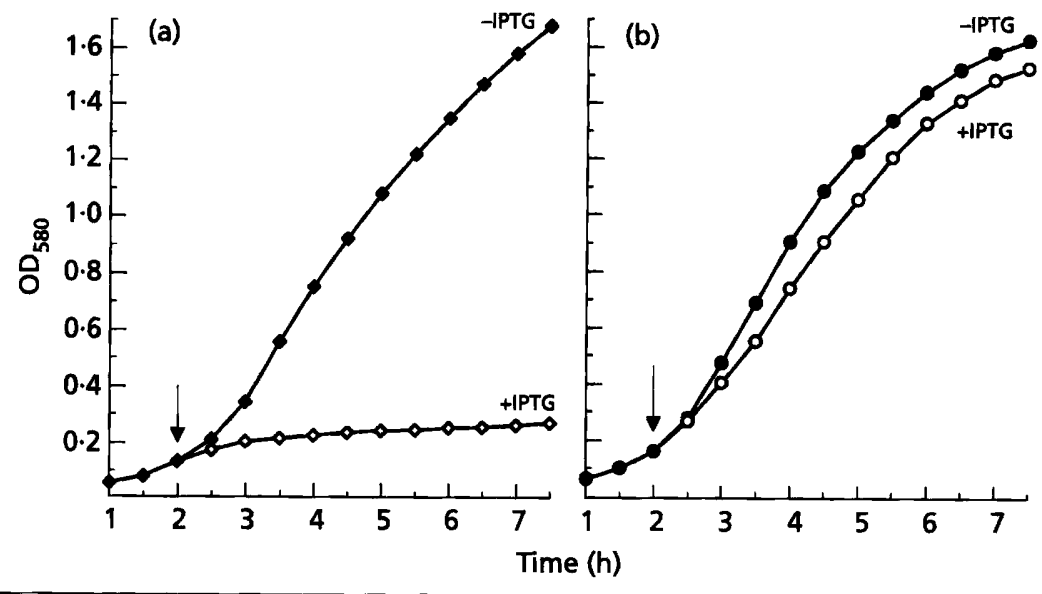

Fig. 4. Reversal of growth inhibition of $E$. coli due to the overexpressed relA gene by the overexpressed rel gene of $C$. glutamicum. Overnight cultures of $E$. coli CF1648, transformed with pSFS10 and either pK18mob (a) or pLW68 (b), were diluted 1:50 in fresh LBG medium and induced at $O D_{580} 0.15$ by the addition of IPTG at a final concentration of $2 \mathrm{mM}$. Cultivations were done in $500 \mathrm{ml}$ Erlenmeyer flasks with $100 \mathrm{ml}$ LBG at $37^{\circ} \mathrm{C}$ and 180 r.p.m., and aliquots for the determination of $O D_{580}$ were taken at the time intervals given. Values are means of at least three different experiments.

hibits tRNA ${ }^{\text {Ser }}$ aminoacylation, and L-valine, resulting in isoleucine starvation (Cashel et al., 1996). The comigration of putative ${ }^{32} \mathrm{P}_{\mathrm{i}}$-labelled (p)ppGpp with unlabelled marker (p)ppGpp visualized by UV absorbance was verified by two-dimensional chromatography of C. glutamicum samples. As expected, under normal growth conditions none of the strains tested showed an accumulation of ( $\mathrm{p}$ )ppGpp (data not shown). After induction of amino acid starvation we detected (p)ppGpp in nucleotide extracts of C. glutamicum ATCC 13032, RES167 and RM4, which comigrates with (p)ppGpp synthesized by the E. coli wild-type under similar conditions (Fig. 3). The spot corresponding to pppGpp is present only in relatively minor amounts in all three C. glutamicum strains, indicating that, as in $E$. coli, ppGpp is the major accumulation product. The apparently lower (p)ppGpp quantities in C. glutamicum relative to those of $E$. coli were probably due to the rapid screening method used in our experiments, since nonuniform nucleotide labelling is not linear either with time or with cell density (Cashel, 1994). In contrast, we observed no (p)ppGpp accumulation in E. coli CF1652 $(\Delta r e l A)$ or in the rel mutant strains of RES167 and RM4 upon amino acid deprivation. These findings indicate that the synthesis of ( $p$ )ppGpp under amino acid starvation conditions in C. glutamicum depends on a functional rel gene.

\section{E. coli growth defects caused by an overexpressed relA gene can be corrected in the presence of an overexpressed C. glutamicum rel gene}

After identification of $r e l$ as a gene encoding a functional (p)ppGpp synthetase, we addressed the question of whether there is a second orthologous gene functioning in (p)ppGpp breakdown. Attempts to identify a second relA/spoT homologue in C. glutamicum made use of heterologous hybridization experiments with 24 oligonucleotides designed according to highly conserved regions in SpoT of E. coli and M. leprae and the Rel proteins of $S$. equisimilis and C. glutamicum, using the preferred codons of corynebacteria (Malumbres et al., 1993). Since these experiments (data not shown) gave no evidence for the presence of a second relA/spoT homologous gene in C. glutamicum, the possibility arose that the C. glutamicum rel gene might substitute for both functions encoded by the relA and spoT genes in $E$. coli. This idea was supported by findings in $B$. subtilis (Wendrich \& Marahiel, 1997) and S. equisimilis (Mechold et al., 1996; Mechold \& Malke, 1997), where most probably only one relA/spoT-like gene exists. Mutations affecting the SpoT (p)ppGpp hydrolase activity in E. coli, like the spoT203 allele, which was obtained by hydroxylamine mutagenesis, result in a slow-growth phenotype due to elevations of ( $p$ )ppGpp levels (Xiao et al., 1991). The massive overexpression of the E. coli relA gene in $E$. coli relA ${ }^{+}$spo $T^{+}$strains results in 20- to 50-fold higher (p)ppGpp levels as compared to normal conditions of amino acid starvation and in a complete inhibition of growth (Schreiber et al., 1991; Svitil et al., 1993). The spoT203-dependent growth defect is abolished by coexpression of $s p o T$ due to its functional (p)ppGpp hydrolase activity, restoring a low (p)ppGpp level (Xiao et al., 1991). Therefore, we analysed whether the overexpressed C. glutamicum rel gene is able to reverse the $E$. coli growth inhibition caused by strong overexpression of the relA gene, which would provide evidence for a (p)ppGpp-degrading function of the Rel protein.

The uninterrupted rel gene was isolated by using the plasmid rescue technique. For this purpose, an $800 \mathrm{bp}$ EcoRI-BamHI fragment located upstream of apt was inserted into $\mathrm{pK} 18 \mathrm{mob}$. After integration of the resulting plasmid pLW60 (Fig. 1) into the chromosome of C. glutamicum RES167, a HindIII rescue was carried out to obtain pLW65 with an $4.75 \mathrm{~kb}$ insert, representing the complete apt-rel region. Finally, a $3.5 \mathrm{~kb}$ Xhol-HindIII subfragment of the pLW65 insert was cloned into pK18mob, yielding $\mathrm{pLW} 68$, bearing rel under the control of the inducible lac promoter.

The complete $E$. coli rel $A$ gene, including the ribosomebinding site but without its own promoter, was amplified from the chromosome of $E$. coli CF1648 using PCR and cloned into SmaI-digested plasmid pTrc99A. The resulting vector pSFS10 carries a $2.5 \mathrm{~kb}$ fragment harbouring relA downstream of the IPTG-inducible $t r c$ 
promoter. The functionality of the amplified relA gene was verified by its ability to abolish the SMG sensivity of an E. coli relA strain (Uzan \& Danchin, 1976). SMG sensivity means that the growth of $E$. coli relA mutant strains, like DH5 $\alpha \mathrm{MCR}$ (relA1), is prevented in minimal medium supplemented with the one-carbon-pool amino acids serine, methionine and glycine (SMG). When introduced into DH5 $\alpha \mathrm{MCR}$, pSFS10 enables growth of the strain on SMG plates (data not shown).

The E. coli strain CF1648 was transformed with pSFS10 (E. coli relA) and either pLW68 (C. glutamicum rel), or the control plasmid pK18mob. The effect of IPTG induction on growth of CF1648 containing the different pairs of plamids was determined by measuring $\mathrm{OD}_{580}$ of the growth medium. As shown in Fig. 4(a), induction of pSFS10 gives complete growth inhibition. In contrast, the presence of pLW68 abolishes growth inhibition (Fig 4b), thereby suggesting a (p)ppGppase activity conferred by the C. glutamicum rel gene. Alternative explanations for the suppression of the $E$. coli growth defect, for example that the $E$. coli RelA synthetase activity could be inhibited by the C. glutamicum Rel protein, seemed to be less likely.

\section{DISCUSSION}

In E. coli two related genes, relA and spoT, function in the metabolism of the stringent response regulator (p)ppGpp. Since sequence information of $\mathrm{relA} / \mathrm{spoT}$ homologous genes from several Gram-positive and Gram-negative bacteria was available, we applied a PCR-based strategy to isolate an equivalent from $C$. glutamicum. The entire rel gene was cloned by applying integration mutagenesis and the plasmid rescue technique. The deduced Rel protein shows strong similarities to all known RelA/SpoT orthologues. There is also a high degree of conservation in gene organization of the isolated region in bacteria related to C. glutamicum. In C. glutamicum rel is preceded by two ORFs that are similar to apt, encoding an adenine phosphoribosyltransferase (Hershey \& Taylor, 1986), and dciAE, acting as a peptide-binding protein as part of a dipeptide transport system (Mathiopoulos et al., 1991). The apt genes of Mycoplasma genitalium (Fraser et al., 1995) and Mycoplasma pneumoniae (Himmelreich et al., 1996) are located in front of their spoT genes, separated only by a small ORF of unknown function. In Streptomyces coelicolor A3(2) (Chakraburtty et al., 1996), Bacillus subtilis (Wendrich \& Marahiel, 1997), Mycobacterium leprae (EMBL U00011) and Mycobacterium tuberculosis (Z77724), the relA/spoT homologues are preceded directly by apt-like genes. Additionally, the dciAE genes of M. leprae and M. tuberculosis are found immediately upstream of the respective apt genes. While the stringent response regions in Gram-positive bacteria appear extensively conserved, the corresponding regions of relA and/or spoT homologous genes in Gramnegative organisms, for example E. coli (Sarubbi et al.,
1988; Metzger et al., 1988), Haemophilus influenzae (Fleischmann et al., 1995) and Vibrio sp. S14 (Flärdh et al., 1994), are different from C. glutamicum and appear considerably more variable.

The analysis of the C. glutamicum Rel sequence failed to identify a putative ATP/GTP-binding domain. Moreover, neither in SpoT of M. leprae and Rel of Streptococcus equisimilis, nor in the Rel-like proteins of E. coli and Vibrio sp., is such a motif present. Only Streptomyces coelicolor A3(2) RelA contains a 'P-loop' consensus sequence probably involved in ATP/GTP-binding (amino acid residues 458-465) (Martinez-Costa et al., 1996), which is surprising, since all enzymes involved in (p)ppGpp metabolism have to bind phosphate as a substrate for their catalytic activity. Nevertheless, a mutational analysis of SpoT from E. coli identified its amino residues $85-376$ as being responsible for binding ATP, GTP or GDP (Gentry \& Cashel, 1996). This corresponds to a region in the C. glutamicum Rel protein (residues 113-402) which shares a high degree of similarity to SpoT, providing evidence that this region of the Rel protein might be involved in binding of phosphate.

Since Rel of C. glutamicum is highly similar to both $E$. coli RelA and E. coli SpoT, it might represent a functional homologue of RelA, encoding a (p)ppGpp synthetase, or of SpoT, involved in (p)ppGpp degradation rather than synthesis. The rel-like genes of Mycoplasma genitalium, Mycoplasma pneumoniae, Mycobacterium leprae and Mycobacterium tuberculosis were identified during genome sequencing projects and all termed spoT. However, this designation is based on the slightly higher degree of sequence homology to $E$. coli spoT than to relA. A functional analysis was carried out for the relA genes of $S$. coelicolor $A 3(2)$ and $B$. subtilis, which have been shown to encode enzymes with (p)ppGpp synthetase activity (Chakraburtty et al., 1996; Wendrich \& Marahiel, 1997). (p)ppGpp accumulation assays in C. glutamicum wild-type and rel mutant strains, which lack a central 400 bp fragment (corresponding to amino acid residues 129-266), established that the rel gene encodes a (p)ppGpp synthetase. Synthesis of (p)ppGpp invoked by amino acid starvation was abolished in the rel mutants but not in the wild-type strains, a phenotype described for relA mutants of $E$. coli (Cashel et al., 1996). As a result, further attempts to isolate a functional orthologue of the E. coli spoT gene were performed. However, heterologous hybridization experiments failed to identify a second relA/spoT homologue in C. glutamicum. Thus, it appeared possible that the rel gene encodes the functions residing in two $E$. coli genes. This thesis is supported by the following findings in several other organisms. (i) Data obtained from genome sequencing projects of Mycobacterium leprae and Mycobacterium tuberculosis (URL http: //kiev.physchem.kth.se/MycDB.html), Streptococcus pyogenes (URL http://dna1.chem.uoknor.edu), Helicobacter pylori (Tomb et al., 1997), Mycoplasma genitalium (Fraser et al., 1995), Mycoplasma pneumoniae (Himmelreich et al., 1996) and Bacillus subtilis (URL 
http://138.102.88.140) reveal the appearance of only one rel equivalent in each of these bacteria. (ii) A chromosomal deletion in the relA gene of $B$. subtilis (Wendrich \& Marahiel, 1997) has been shown to inactivate (p)ppGpp accumulation upon amino acid deprivation, as in E. coli relA mutants, as well as upon glucose exhaustion, a phenotype caused by certain spoT mutations in E. coli (Gentry \& Cashel, 1996). (iii) The $S$. equisimilis H46A rel gene, like E. coli spoT, is bifunctional, encoding a strong (p)ppGppase and a weaker ribosome-independent (p)ppGpp synthetase. However, a rel insertion mutant fails to accumulate (p)ppGpp following amino acid starvation (Mechold et al., 1996), a behaviour characteristic of $E$. coli relA but not spoT mutants.

In C. glutamicum an additional hint came from rel expression studies in E. coli, also giving evidence for a (p)ppGpp-degrading activity of the Rel protein. Growth inhibition, caused by overexpression of the $E$. coli relA gene, leading to increasing amounts of (p)ppGpp, could be reversed by the C. glutamicum rel gene. There may be other reasons for this behaviour; for example the E. coli relA gene product could be inactivated by the $C$. glutamicum Rel protein or rel gene expression might inhibit IPTG induction of active RelA protein. However, we strongly favour our conclusion, since similar experiments with the rel gene of $S$. equisimilis have shown almost identical results and the (p)ppGppase activity of the Rel protein deduced from these experiments could be verified in vitro (Mechold et al., 1996).

Taken together, the data presented in this study make it likely that the rel gene of C. glutamicum is bifunctional, encoding a (p)ppGpp synthetase as well as a (p)ppGppdegrading enzyme activity. The results also lead to the proposal that the metabolism of (p)ppGpp in $C$. glutamicum is mainly mediated by a single rel gene, which fulfils the functions that reside in the $r e l A$ and spoT genes of $E$. coli. In addition, recent findings in $C$. glutamicum have indicated that RNA synthesis and growth rate are inversely correlated with the cellular ppGpp concentration (Ruklisha et al., 1995), supporting an essential role of the rel gene in the stringent response of C. glutamicum.

\section{ACKNOWLEDGEMENTS}

We thank A. Tauch for helpful discussion and critical reading of the manuscript. The E. coli strains CF1648 and CF1652 were kindly provided by M. Cashel (Bethesda, USA). This work was supported by grant 0310626 of the BMBF in collaboration with Degussa AG and by contract no. Bio-4-CT960145 from the European Commission.

\section{REFERENCES}

Altschul, S. F., Gish, W., Miller, W., Myers, E. W. \& Lipman, D. J. (1990). Basic local alignment search tool. J Mol Biol 215, 403-410.

Amann, E., Ochs, B. \& Abel, K.-J. (1988). Tightly regulated tac promotor vectors useful for the expression of unfused and fused proteins in Escherichia coli. Gene 69, 301-315.
An, G., Justesen, J., Watson, R. J. \& Friesen, J. D. (1979). Cloning the spoT gene of Escherichia coli: identification of the spoT gene product. J Bacteriol 137, 1100-1110.

Berg, J. M. (1986). Potential metal-binding domains in nucleic acid binding proteins. Science 232, 485-487.

Burkovski, A., Weil, B. \& Krämer, R. (1995). Glutamate excretion in Escherichia coli: dependency on the relA and spoT genotype. Arch Microbiol 164, 24-28.

Cashel, M. (1994). Detection of (p)ppGpp accumulation patterns in Escherichia coli mutants. In Methods in Molecular Genetics, vol. 3, Molecular Microbiology Techniques, Part A, pp. 341-356. Edited by K. W. Adolph. New York: Academic Press.

Cashel, M., Gentry, D. R., Hernandez, V. J. \& Vinella, D. (1996). The stringent response. In Escherichia coli and Salmonella: Cellular and Molecular Biology, 2nd edn, pp. 1458-1496. Edited by F. C. Neidhardt and others. Washington, DC: ASM Press.

Chakraburtty, R., White, J., Takano, E. \& Bibb, M. (1996). Cloning, characterization and disruption of a (p)ppGpp synthetase gene (relA) of Streptomyces coelicolor A3(2). Mol Microbiol 19, 357-368.

Cochran, J. W. \& Byrne, R. W. (1974). Isolation and properties of a ribosome-bound factor required for ppGpp and pppGpp synthesis in Escherichia coli. J Biol Chem 249, 353-360.

Codon, C., Squires, C. \& Squires, C. L. (1995). Control of rRNA transcription in Escherichia coli. Microbiol Rev 59, 623-645.

Flărdh, K., Axeberg, T., Albertson, N. H. \& Kjelleberg, S. (1994). Stringent control during carbon starvation of marine Vibrio sp. Strain S14: molecular cloning, nucleotide sequence, and deletion of the relA gene. J Bacteriol 176, 5949-5957.

Fleischmann, R. D., Adams, M. D., White, O. \& 37 other authors (1995). Whole-genome random sequencing and assembly of Haemophilus influenzae Rd. Science 269, 496-512.

Fraser, C. M., Gocayne, J. D., White, O., Adams, M. D., Clayton, R. A., Fleischmann, R. D., Bult, C. J., Kerlavage, A. R., Sutton, G. \& Kelley, J. M. (1995). The minimal gene complement of $M y c 0$ plasma genitalium. Science 270, 397-403.

Gentry, D. R. \& Cashel, M. (1996). Mutational analysis of the Escherichia coli spoT gene identifies distinct but overlapping regions involved in ppGpp synthesis and degradation. Mol Microbiol 19, 1373-1384.

Goldman, E. \& Jakubowski, H. (1990). Uncharged tRNA, protein synthesis, and the bacterial stringent response. Mol Microbiol 4, 2035-2040.

Grant, S. G. N., Jessee, J., Bloom, F. R. \& Hanahan, D. (1990). Differential plasmid rescue from transgenic mouse DNAs into Escherichia coli methylation-restriction mutants. Proc Natl Acad Sci USA 87, 4645-4649.

Hawley, D. K. \& McClure, W. R. (1983). Compilation and anlaysis of Escherichia coli promotor sequences. Nucleic Acids Res 11, 2237-2255.

Hernandez, V. J. \& Bremer, H. (1991). Escherichia coli ppGpp synthetase II requires spoT. J Biol Chem 266, 5991-5999.

Hershey, H. V. \& Taylor, M. W. (1986). Nucleotide sequence and deduced amino acid sequence of Escherichia coli adenine phosphoribosyltransferase and comparision with other analogous enzymes. Gene 43, 287-293.

Himmelreich, R., Hilbert, H., Plagens, H., Pirkl, E., Li, B. C. \& Herrmann, R. (1996). Complete sequence analysis of the genome of the bacterium Mycoplasma pneumoniae. Nucleic Acids Res 24, $4420-4449$. 
Malumbres, M., Gil, J. A. \& Martin, J. F. (1993). Codon preferences in corynebacteria. Gene 134, 15-24.

Martinez-Costa, O. H., Arias, P., Romero, N. M., Parro, V., Mellado, R. P. \& Malpartida, F. (1996). A relA/spoT homologous gene from Streptomyces coelicolor A3(2) controls antibiotic biosynthesis genes. J Biol Chem 271, 10627-10634.

Mathiopoulos, C., Mueller, J. P., Slack, F. C., Murphy, C. G., Patankar, S., Bukusoglu, G. \& Sonenshein, A. L. (1991). A Bacillus subtilis dipeptide transport system expressed early during sporulation. Mol Microbiol 5, 1903-1913.

Mechold, U. \& Malke, H. (1997). Characterization of the stringent and relaxed responses of Streptococcus equisimilis. $J$ Bacteriol 179, 2658-2667.

Mechold, U., Steiner, K., Vettermann, S. \& Malke, H. (1993). Genetic organization of the streptokinase region of the Streptococcus equisimilis H46A chromosome. Mol Gen Genet 241, 129-140.

Mechold, U., Cashel, M., Steiner, K., Gentry, D. \& Malke, H. (1996). Functional analysis of a relA/spoT gene homolog from Streptococcus equisimilis. J Bacteriol 178, 1401-1411.

Metzger, S., Ben Dror, I., Aizenman, E., Schreiber, G., Toone, M., Friesen, J. D., Cashel, M. \& Glaser, G. (1988). The nucleotide sequence and characterization of the relA gene of Escherichia coli. $J$ Biol Chem 263, 15699-15704.

Metzger, S., Sarubbi, E., Glaser, G. \& Cashel, M. (1989). Protein sequences encoded by the relA and spoT genes of Escherichia coli are interrelated. J Biol Chem 264, 9122-9125.

Murray, K. D. \& Bremer, H. (1996). Control of spoT-dependent ppGpp synthesis and degradation in Escherichia coli. J Mol Biol 259, 41-57.

Patek, M., Eikmanns, B. J., Patek, J. \& Sahm, H. (1995). Promotors from Corynebacterium glutamicum: cloning, molecular analysis and search for a consensus motif. Microbiology 142, 1297-1309.

Pearson, W. R. \& Lipman, D. J. (1988). Improved tools for biological sequence comparison. Proc Natl Acad Sci USA 85, 2444-2448.

Ruklisha, M., Viesturs, U. \& Labane, L. (1995). Growth control and ppGpp synthesis in Brevibacterium flavum cells at various medium mixing rates and aeration intensities. Acta Biotechnol 15, 41-48.

Ryals, J., Little, R. \& Bremer, H. (1982). Control of rRNA and tRNA synthesis in Escherichia coli by guanosine tetraphosphate. $J$ Bacteriol 151, 1261-1268.

Sahm, H., Eggeling, L., Eikmanns, B. J. \& Krämer, R. (1995). Metabolic design in amino acid producing bacterium Corynebacterium glutamicum. FEMS Microbiol Lett 16, 243-252.

Sambrook, J., Fritsch, E. F. \& Maniatis, T. (1989). Molecular Cloning: a Laboratory Manual, 2nd edn. Cold Spring Harbor, NY: Cold Spring Harbor Laboratory.

Sanger, F., Nicklen, F. \& Coulson, A. R. (1977). DNA sequencing with chain-terminating inhibitors. Proc Natl Acad Sci USA 74, 5463-5467.

Sarrubi, E., Rudd, K. E., Xlao, H., Ikehara, K., Kalman, M. \& Cashel, M. (1988). Characterization of the spoT gene of Escherichia coli. J Biol Chem 264, 15074-15082.

Schäfer, A., Kalinowski, J., Simon, R., Seep-Feldhaus, A.-H. \&
Puhler, A. (1990). High-frequency conjugal plasmid transfer from Gram-negative Escherichia coli to various Gram-positive coryneform bacteria. J Bacteriol 172, 1663-1666.

Schäfer, A., Tauch, A., Jăger, W., Kalinowski, J., Thierbach, G. \& Puhler, A. (1994). Small mobilizable multi-purpose cloning vectors derived from Escherichia coli plasmids pK18 and pK19: selection of defined deletions in the chromosome of Corynebacterium glutamicum. Gene 145, 69-73.

Schreiber, G., Metzger, S., Aizenman, E., Roza, S., Cashel, M. \& Glaser, G. (1991). Overexpression of the relA gene in Escherichia coli. J Biol Chem 266, 3760-3767.

Simon, R., Priefer, U. \& Puhler, A. (1983). A broad host range mobilization system for in vivo genetic engineering: transposon mutagenesis in Gram-negative bacteria. Bio/Technology 1, 784-794.

Staden, R. (1986). The current status and portability of our sequence handling software. Nucleic Acids Res 14, 217-232.

Suggs, S. V., Hirose, T., Miyake, T., Kawashima, E. H., Johnson, M. J., Itakura, K. \& Wallace, R. B. (1981). Use of synthetic oligodeoxyribonucleotides for the isolation of specific cloned DNA sequences. In Developmental Biology Using Purified Genes, pp. 683-693. Edited by D. D. Brown \& C. F. Fox. New York: Academic Press.

Svitil, A. L., Cashel, M. \& Zyskind, J.W. (1993). Guanosine tetraphosphate inhibits protein synthesis in vivo: a possible protective mechanism for starvation stress in Escherichia coli. $J$ Biol Chem 268, 2307-2311.

Tauch, A., Kirchner, O., Wehmeier, L., Kalinowski, J. \& Puhler, A. (1994). Corynebacterium glutamicum DNA is subjected to methylation-restriction in Escherichia coli. FEMS Microbiol Lett 123, 343-347.

Tauch, A., Kassing, F., Kalinowski, J. \& Pühler, A. (1995). The Corynebacterium xerosis composite transposon Tn5432 consists of two identical insertion sequences, designated IS1249, flanking the erythromycin resistance gene ermCX. Plasmid 34, 119-131.

Thompson, J. D., Higgins, D. G. \& Gibson, T. J. (1994). CLUSTAL W : improving the sensitivity of progressive multiple sequence alignment through sequence weighting, position-specific gap penalties and weight matrix choice. Nucleic Acids Res 22, 4673-4680.

Tomb, J. F., White, O., Kerlavage, A. R. \& 22 other authors (1997). The complete genome sequence of the gastric pathogen Helicobacter pylori. Nature 388, 539-547.

Uzan, M. \& Danchin, A. (1976). A rapid test for the relA mutation in Escherichia coli. Biochem Biophys Res Commun 69, 751-758.

Wendrich, T. M. \& Marahiel, M. A. (1997). Cloning and characterization of a relA/spoT homologue from Bacillus subtilis. Mol Microbiol 26, 65-79.

Wohlleben, W., Muth, G. \& Kalinowski, J. (1993). Genetic engineering of Gram-positive bacteria. In Genetic Engineering of Microorganisms, pp. 83-133. Edited by A. Pühler. New York: Weinheim.

Xiao, H., Kalman, M., Ikehara, K., Zemel, Z., Glaser, G. \& Cashel, M. (1991). Residual guanosine $3^{\prime}, 5^{\prime}$-bispyrophosphate synthetic activity of relA null mutants can be eliminated by spoT null mutations. J Biol Chem 266, 5980-5990.

Received 12 January 1998; revised 16 March 1998; accepted 19 March 1998. 